\title{
French science after Chirac
}

\section{Presidential elections next spring are set to lend fresh impetus to research reform in France.}

\section{/ /}

-ime for a French revolution", "A chance for change in France", "France's research base needs a shaking", "A squandered opportunity", "France: too much analysis leads to paralysis?". These headlines from Nature have punctuated more than a decade of successive opportunities, false starts and failures in the reform of France's research system.

Is French science, and indeed France itself, now ready for a longoverdue renewal? The country is plagued with high unemployment, strained public finances and a faltering economy. Its overall scientific effort has stagnated for more than a decade. Yet meaningful reform of either French society or its research system have proved elusive, with a vicious spiral of inept attempted change and spirited, usually successful, resistance making reform seem almost impossible.

To believe that France is somehow unreformable would be simplistic, however, and there is currently good reason to be optimistic. Next year's presidential election offers the hope of a fresh start. The favourites for the election, socialist Ségolène Royal and conservative Nicolas Sarkozy, have each built their campaigns on their youth and the need for radical change. That matches the mood of the country, which seems ready to embrace a break with a passing political generation that seems ineffective and out of touch.

In science too there are signs of change. Jacques Chirac's two terms of office have seen an overall decline in French science, and an unprecedented level of disharmony between scientists and the government. The administration has shown a disregard for science and a penchant for attempting to implement change without consultation, and has made deep cuts in science budgets and jobs. But given the likelihood of an improved climate after the presidential election, there are signs that France may be ready to modernize its research system.

To its credit, the Chirac administration has created some of the tools that could enable change. In particular, it has set up a National Research Agency (ANR) to distribute research funds on the basis of grant proposals, creating greater competition than previously existed, when funds were largely distributed to laboratories directly.

Researchers seem to have now accepted the principle of the shift to this more Anglo-Saxon dual system of labs and competitive funds. But they remain deeply sceptical of the agency itself, which to many looks like an arm of government destined to centralize control over research, lacking the scientific autonomy and authority of, say, the US National Science Foundation. This scepticism has some basis, and given the government's general neglect of science, it is unsurprising that the scientific community has not fully accepted the new agency.

The principle behind the ANR is sound, however. Corresponding shifts seem also to be under way at the CNRS, Europe's largest basic research agency, which early next year will present a series of reforms, probably including higher salaries for researchers who score better on international performance indicators, and a focusing of resources on fewer areas of excellence. Such changes are needed at an agency notorious for being inflexible and bureaucratic.

CNRS management has already created controversy this month by announcing that it will rein back support for the life sciences, except for neurosciences and systems biology, claiming that researchers' performance is not up to scratch in this sector, which consumes a third of the agency's budget. It is promising that the CNRS seems willing to make tougher choices with its own budget, to support excellence while maintaining a balance of disciplines.

This should also, however, provoke a wider debate on the country's overall research priorities. It is true that the impact of France's life sciences in international publications is below that of other fields, such as mathematics and physics. But this also reflects the fact that France, with its focus on large programmes in aerospace and nuclear
"Many in the French research community yearn for a more modern, more competitive and less bureaucratic research system." research, has given life sciences less support than has Britain, for example. If French life sciences are less than competitive, it is partly because they have never been given the means to become so.

Despite a tradition of resistance to change, many in the French research community yearn for a more modern, more competitive and less bureaucratic research system that would give the brightest young researchers the autonomy they need to take French science forward. The next president of France, and the government that he or she appoints, will have a crucial role in making research a genuine priority, and working with, rather than against, the scientific community. French science can ill afford yet another false start.

\section{Smiles all round}

\section{Can research buy you happiness?}

W hen physicist Paul Rothemund of the California Institute of Technology created smiley faces by the billion out of self-assembling pieces of DNA (Nature 440, 297-302; 2006) - an achievement celebrated on the cover of this journal - it gave his friend and colleague Erik Winfree a nice opportunity to joke that the work represented "the most concentrated happiness ever created". But in general, although happiness may often be a by-product of scientific research - most notably for the researchers themselves its direct production, let alone its concentration, is not.

Yet happiness is not a purely subjective phenomenon, immune to scientific analysis. As we report on page 418 , it is a focus of interest on the parts of both researchers and policy-makers. A growing number of people are calling for happiness, and measures to enhance it, to 